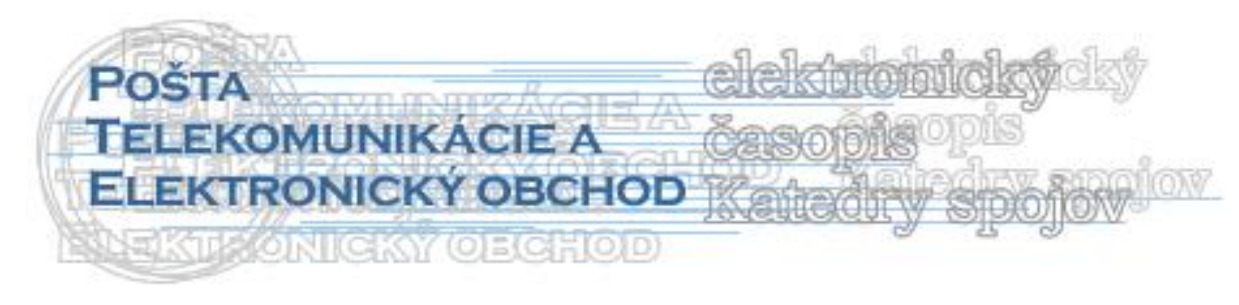

\title{
TELEMARKETING - EFEKTÍVNA FORMA PRIAMEHO MARKETINGU
}

\author{
Ing. Milan Kubina, PhD., Ing Viliam Lendel*
}

\section{Úvod}

Telemarketing je dnes už bežnou súčast'ou života moderného človeka. Súčasný človek totiž hl'adá možnost', ako ušetrit' čas, a tak využíva výhody, ktoré mu poskytuje telefón či internet. Firmy používajú telemarketing, pretože im umožňuje zrýchlenie komunikácie s klientom, štandardizované predstavenie ponuky klientovi, komfortné zistenie dát o klientovi, atd'. Klienti si zase zvykli na príjemný hlas v telefóne, ktorý ich vedie, pomáha im riešit' momentálnu situáciu bez toho, aby museli opustit' svoj domov.

Telemarketing patrí medzi efektívne formy priameho marketingu, je založený na telefónnom kontaktu s potenciálnymi alebo existujúcimi zákazníkmi. Člení sa na dve základné formy, a to na:

- aktívny telemarketing

- pasívny telemarketing

\section{Základné členenie telemarketingu}

L’udia väčšinou chápu pojem telemarketing rôzne. Bud' ako termín len pre objednávkové, predajné telefonáty, alebo ako komplex aktívnych (odchádzajúcich) a pasívnych (prichádzajúcich) hovorov. Z praxe vyplýva, že výstižnejšie poňatie predstavuje celkový súbor všetkých telefonických hovorov, teda ako odchádzajúcich, tak i prichádzajúcich.

\section{Pasívny telemarketing}

Pasívny telemarketing je spracovanie prichádzajúcich telefónnych hovorov. $\mathrm{Na}$ určenom telefónnom čísle, ktoré je spravidla zverejňované v médiách, operátori prijímajú prichádzajúce hovory a príslušným spôsobom ich spracovávajú. Tieto hovory v skutočnosti v žiadnom prípade nepatria k pasívnym. Ani operátori pasívne nesedia a nečakajú, až im niekto zavolá.

\footnotetext{
* Ing. Milan Kubina, PhD., Ing. Viliam Lendel, Katedra menežérskych teórií, FRI, ŽU tel.: +421-41-5134323, fax: +421-41-5134451

e-mail: milan.kubina@fri.uniza.sk, Viliam.lendel@fri.uniza.sk
} 
Využitie môže byt' nasledujúce:

- info linky - predstavujú linky, na ktorých môžu zákazníci získat' informácie o produkte, dozvediet' sa o pripravovaných novinkách či aktuálnej ponuke. Poskytnuté informácie môžu mat' zásadný vplyv na zákazníkovo rozhodnutie o kúpe, alebo môžu zvládnut' negatívne reakcie pri reklamáciách. Na týchto linkách je možné plnit' informačnú povinnost' alebo dostat' do povedomia verejnosti informácie, ktoré považujeme za konkurenčnú výhodu,

- objednávky propagačných materiálov,

- sút'aže - pokial' sa spoločnost' rozhodne usporiadat' spotrebitel'skú sút'až, nevyhnutnou súčast'ou propagačných materiálov by malo byt' aj telefónne číslo, na ktorom operátori poskytnú bližšie informácie o podmienkach účasti v sút'aži a o jej pravidlách,

- reklamácie a st’ažnosti,

- help line,

- príjem faxu,

- fax on demand (fax na vyžiadanie - napríklad pre nové informácie).

Tabul'ka 1 Výhody a nevýhody pasívneho telemarketingu [1]

\begin{tabular}{|c|c|}
\hline Výhody & Nevýhody \\
\hline $\begin{array}{l}\text { - jednoduchší výber operátorov, } \\
\text { vel'mi dobré poznajú produkty, služby } \\
\text { a procesy, } \\
\text { operátori sa stávajú špecialistami na } \\
\text { produkt. }\end{array}$ & $\begin{array}{l}\text { - } \quad \text { oddelená skupina operátorov, } \\
\text { - } \quad \text { nie všetci majú schopnosti predávat', } \\
\text { - } \quad \text { nie vždorých nejde univerzálne využívat', } \\
\text { nie vyt'ažení. }\end{array}$ \\
\hline
\end{tabular}

\section{Aktívny telemarketing}

Aktívny telemarketing predstavuje ponúkanie služieb a produktov po telefóne, teda spracovanie odchádzajúcich telefónnych hovorov. Operátori kontaktujú dopredu vybranú skupinu zákazníkov. V niektorých prípadoch taktiež po telefóne zjednávajú schôdzky obchodníkom alebo priamo uzavierajú objednávky.

Ciel'om hovorov je: [1]

- prieskum trhu,

- aktualizácia databázy,

- zodpovedanie otázok a vyplnenie dotazníka,

- zistovanie potrieb zákazníkov,

- dohováranie schôdzok pre obchodných zástupcov,

- zist'ovanie spokojnosti zákazníka,

- pod’akovanie klientom, gratulácia k významným výročiam,

- zaznamenávanie reakcií na reklamnú kampaň a podobne.

Tabul'ka 2 Výhody a nevýhody aktívneho telemarketingu [1] 


\begin{tabular}{|c|c|}
\hline Výhody & hody \\
\hline 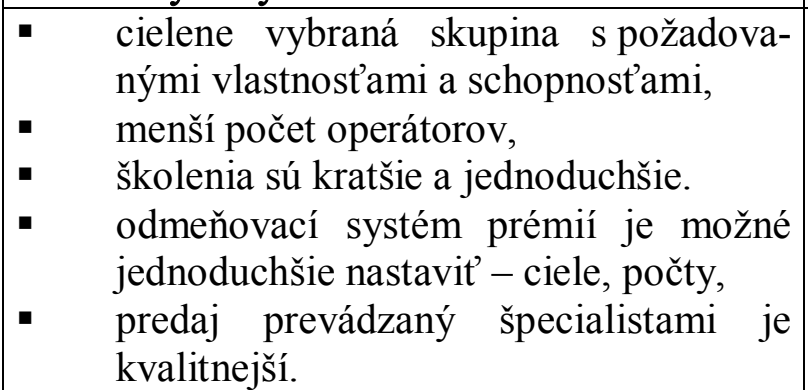 & $\begin{array}{l}\text { - oddelená skupina operátorov, } \\
\text { - úzke zameranie na predaj, } \\
\text { - } \text { poznajú len svoj produkt, } \\
\text { mnohokrát nepoznajú nadväzujúce } \\
\text { procesy spracovania, } \\
\text { v dobe špičiek, ked' volá najviac } \\
\text { klientov, ich nie je možné využívat. }\end{array}$ \\
\hline
\end{tabular}

\section{Oddelený a priamy mix}

Niektoré spoločnosti využívajú operátorov oddelene pre jeden typ hovorov, inde si operátori striedajú odchádzajúce a prichádzajúce hovory počas dňa, tzv. mix. Pri oddelenom mixe operátori čast' pracovnej doby aktívne kontaktujú klientov a zvyšok času vybavujú prichádzajúce hovory. Pri priamom mixe operátori spracovávajú prichádzajúce hovory, v prípade d’alšieho čakania systém automaticky vytáča hovory odchádzajúce.

Tabul'ka 3 Výhody a nevýhody oddeleného a priameho mixu [1]

\begin{tabular}{|l|l|}
\hline Výhody & \multicolumn{1}{|c|}{ Nevýhody } \\
\hline $\begin{array}{l}\text { operátor vie vybavovat' oba typy } \\
\text { hovorov, } \\
\text { pestrejšía práca operátora, } \\
\text { operátori dobre poznajú produkty, stačí } \\
\text { len preškolit' predajné schopnosti, } \\
\text { operatívne vykývajú } \\
\text { v prichádzajúcich hovorov. }\end{array}$ & $\begin{array}{l}\text { nie všetci operátori sú vhodnými typmi } \\
\text { pre striedanie typov hovorov, } \\
\text { obvykle je tu najnižšia úroveñ kvality } \\
\text { predaja, } \\
\text { psychicky je striedanie hovorov pre } \\
\text { operátora vel'mi náročné, } \\
\text { obtiažne sa nastavuje systém prémií, } \\
\text { manažment prevádzky je náročnejší. }\end{array}$ \\
\hline
\end{tabular}

\section{Zákazník a telemarketing}

Vnímanie telemarketingu je u verejnosti rôzne. Na otázku, čo je „telemarketing“ l’udia najčastejšie odpovedali neutrálne, že je to forma reklamy. Negatívne hodnotenie bolo zastúpené častejšie ako pozitívne. Len nepatrná čast' populácie nevie, čo si má pod pojmom „telemarketing“ predstavit’. Výskum bol realizovaný v Českej republike. Najviac zastúpenou skupinou (50 \%) boli odporcovia, ktorí zaujali k telemarketingu negatívny postoj. Telemarketing považujú za nepríjemné obt’ažovanie a podvod, nakol'ko ponúkaný tovar je podl'a nich predražený a nekvalitný. Viac ako štvrtina respondentov (28\%) vníma telemarketing neutrálne. Telemarketing je pre nich formou reklamy alebo lákadlom na tovar, ktorý nie je možné zohnat' iným spôsobom. Priaznivci telemarketingu tvoria 22 \% populácie. Podla nich je telemarketing príjemnou formou nakupovania alebo vhodným spôsobom vyplnenia prestávok v televíznom vysielaní. 


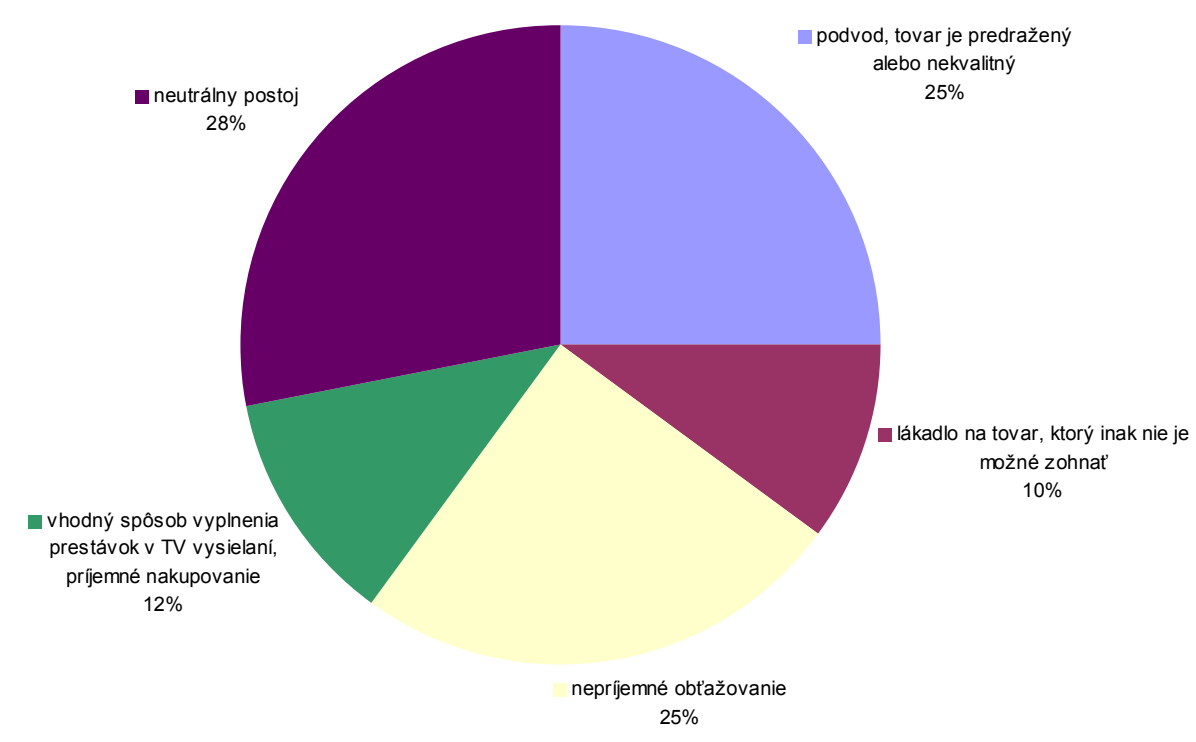

Obrázok 1 Vnímanie telemarketingu u verejnosti [3]

\section{Konkrétne príklady: [3]}

- dohodovanie schôdzok - v tomto prípade sa jedná o aktívny telemarketing zameraný na nových zákazníkov. Klient je cielenými otázkami vedený k dohodnutiu schôdzky.

- prieskum - touto cestou je možné oslovit' vybranú ciel'ovú skupinu respondentov podl'a konkrétnych potrieb, a to na základe vhodne vypracovaného dotazníka pre konkrétny marketingový prieskum. Výstupom je vyhodnotenie a presná analýza.

- predaj - je možné použit' telemarketing aj k priamemu predaju tovarov a služieb.

Aktívny alebo pasívny telemarketing je hlavným komunikačným nástrojom so zákazníkmi, súčast' celkového marketingového komunikačného mixu. Nároky dnešného koncového zákazníka na služby a produkty jednotlivých spoločností sa neustále zvyšujú. Značný vplyv v tejto oblasti má reklama, ktorá zo všetkých strán ovplyvňuje koncových zákazníkov informáciami o porovnatel'ných produktoch alebo službách. S tým rozdielom, aký úžitok z použitia alebo cenu jednotlivé spoločnosti ponúkajú. V podstate neobmedzené možnosti pre porovnávanie produktov a služieb ponúkajú www stránky, obchodné ret’azce sa predbiehajú vo svojich ponukách, a tak si konečný zákazník môže vybrat'.

Aktívny a pasívny telemarketing je nevyhnutnou súčast'ou directmarketingových služieb. Aktívny telemarketing je najviac pre určité ciel'ové skupiny vel'mi účinným predajným kanálom, vel'mi úspešným nástrojom pre follow-up komunikáciu, vel'mi funkčnou podporou pre manažérov predaja alebo rýchlym nástrojom realizácie prieskumov. Pasívny telemarketing zaist'uje spokojnost' volajúceho, a teda i funkčné a zmysluplné naplnenie CRM. 


\section{Záver}

V súčasnosti spoločnosti predovšetkým zaujíma, ako predat’ zákazníkovi čo najviac svojich produktov. Aby tento ciel' úspešne dosiahli, musia vel'mi dobre poznat' svojich zákazníkov, ich zvyky a potreby a vediet' tieto informácie využit' v reklame, ktorá prinesie pozitívny predajný efekt. Tento efekt je možné nakoniec zmerat' a poučit' sa z neho do budúcnosti. Vhodné je použitie aj doplnkových služieb ako e-mailing, direct mailing, SMS marketing, lettershop, výber vhodnej databázy, poradenskú činnost', atd'.

Nenahraditel'nost' telemarketingu spočíva predovšetkým v jeho obrovskej operatívnosti. Je len málo komunikačných nástrojov, kde je možné tak rýchlo menit' ponuku a predchádzat' tak neúspechu kampane. Už pri vykonaní prvých kontaktov, kedy je reakcia zákazníka iná, ako očakáva výrobca, je možné v priebehu niekol'kých minút zmenit' priebeh kampane. Upravit' cielenie, upravit' ponuku alebo len jej formu a tým dosiahnut' rádovo lepších výsledkov, ako keby kampaň prebiehala podl'a pôvodného plánu. [3]

\section{Literatúra}

[1] SANTLEROVÁ, K.: Telemarketing v praxi, GRADA Publishing, Praha, 222 str., ISBN 978-80-247-1536-0

[2] NASH, E.: Direct marketing, COMPUTER Press, Brno, 595 str., ISBN 80-7226-838-4

[3] NOVOTNÝ, P.: Telemarketing, Internetový zdroj

[4] HTTP://WWW.M JOURNAL.CZ/CS/SITE/TEMA/TELEMARKETING2005.HTM 